\title{
Fruit preferences of Malabar Pied Hornbill Anthracoceros coronatus in Western Ghats, India
}

\author{
P. BALASUBRAMANIAN, R. SARAVANAN and B. MAHESWARAN
}

\section{Summary}

Food habits of Malabar Pied Hornbill Anthracoceros coronatus were studied from December 2000 to December 2001, in the Athikadavu valley, Western Ghats, India. A total of 147 individuals belonging to 18 fleshy-fruited tree species were monitored fortnightly. Thirteen fruit species, including five figs and eight non-figs, were recorded in the birds' diet. The overall number of tree species in fruit and fruiting individuals increased with the onset of summer, the Malabar Pied Hornbill's breeding season. The peak in fruiting is attributed to the peak in fruiting by figs. Figs formed the top three preferred food species throughout the year. During the non-breeding period (May to February), 60\% of the diet was figs. During the peak breeding period (March and April), two nests were monitored for 150 hours. Ninety-eight per cent of food deliveries to nest inmates were fruits belonging to six species. Most fruits delivered at the nests constituted figs (75.6\%). In addition, figs sustained hornbills during the lean season and should be considered "keystone species" in the riverine forest ecosystem. Two non-fig species are also important. Habitat features and local threats at Athikadavu valley were assessed. The distribution and conservation status of Malabar Pied Hornbill in the Western Ghats was reviewed. Conservation of hornbill habitats, particularly the lowland riparian vegetation, is imperative.

\section{Introduction}

Malabar Pied Hornbill Anthracoceros coronatus is distributed in India and Sri Lanka as three populations (Kemp 1995): two occur in India, one in the Western Ghats, the other in Eastern India. Within the Western Ghats, distribution of the species is discontinuous (Reddy et al. 1990). Poaching (Ripley 1982, Dev 1992) and habitat destruction (Reddy et al. 1990, Zacharias and Gaston 1999) have caused dramatic population decline during the last decades. The species has been classified as Threatened (Ali and Ripley 1987, Tikadar 1983) and Near Threatened (BirdLife International 2001). The species is frugivorous (Ali and Ripley 1987, Reddy et al. 1990), occurring in mixed deciduous and riparian forests (Reddy et al. 1990) and moist deciduous (Ali and Ripley 1987) forests. Adults have been observed feeding on 17 species of fruits in North Kanara, Western Ghats, especially Ficus and Strychnos nux-vomica (Reddy et al. 1990). This study relates the fruit utilization of Malabar Pied Hornbill to the abundance and availability of food resources. 


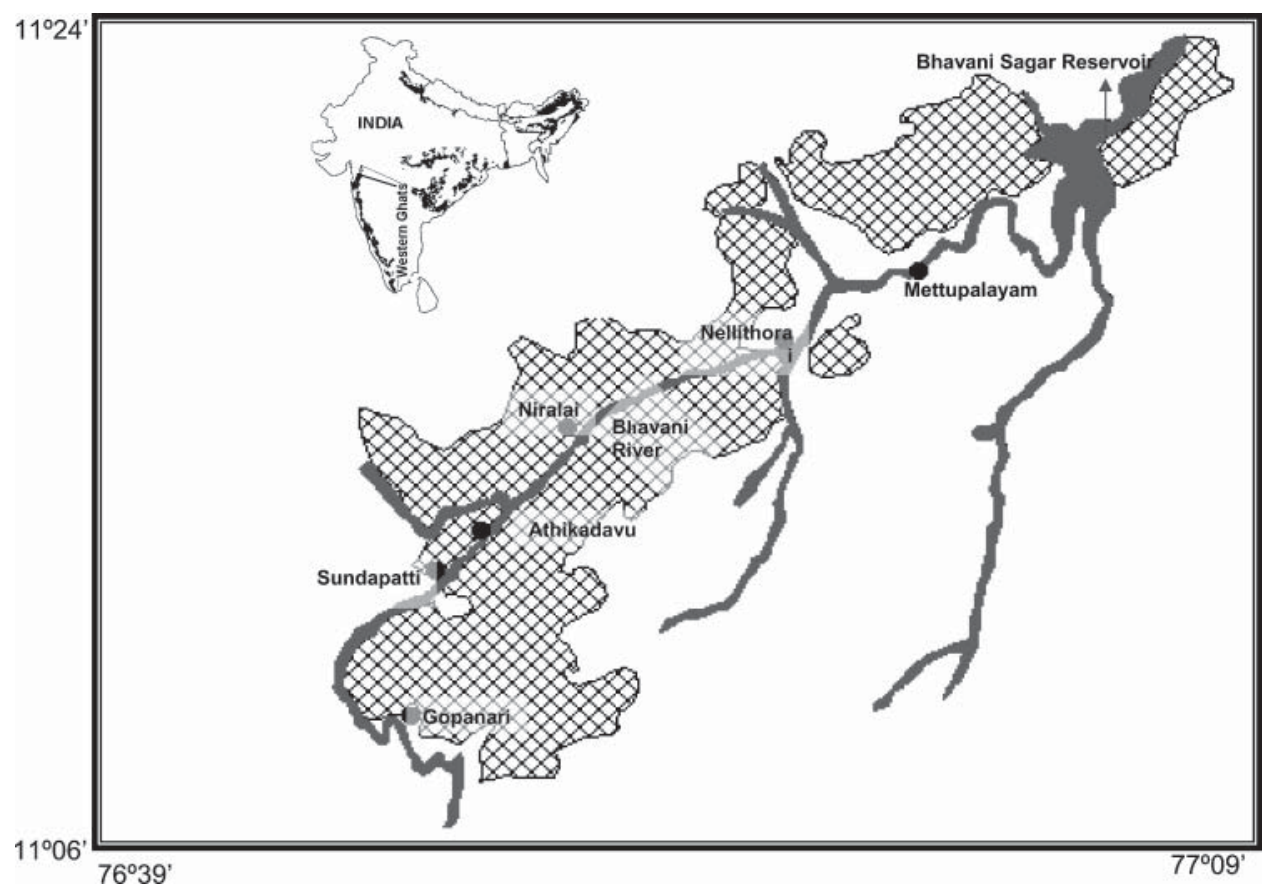

Figure 1. Athikadavu valley in Coimbatore Forest Division, Western Ghats.

\section{Study area and methods}

The study was conducted in riverine forests stretching along the river Bhavani which flows through the reserve forests of Coimbatore division $\left(10^{\circ} 37^{\prime}\right.$ and $11^{\circ} 31^{\prime} \mathrm{N}$ and $76^{\circ} 39^{\prime}$ and $77^{\circ} 5^{\prime} \mathrm{E}$ ) Western Ghats, India (Figure 1). Observations took place in the "Athikadavu valley", $10 \mathrm{~km}$ of riparian vegetation on either side of Athikadavu Bridge. Seasonal monsoon rains occur from June to November and average annual rainfall at the study site ranges from $75 \mathrm{~cm}$ to $120 \mathrm{~cm}$. Summer months are March to May. Average elevation of the valley is $550 \mathrm{~m}$. Vegetation is semi-evergreen forest, mainly seen on the fringes of river Bhavani and dominated by tree species such as Terminalia arjuna (Combretaceae), Mangifera indica (Anacardiaceae) and Madhuca longifolia (Sapotaceae). Flanking the riverbanks is southern dry mixed deciduous forest, dominated by species such as Anogeissus latifolia, Chloroxylon sweitenia and Ixora pavetta (Balasubramanian et al. 1998). Fleshy-fruited, bird-attracting species such as Azadirachta indica, Strychnos potatorum and Santalum album commonly occur here. The study site is rich in wildlife, including large mammalian herbivores such as elephant Elephas maximus and gaur Bos gaurus. Eighty-seven species of birds have been recorded in the riverine forests (Balasubramanian et al. 1998). Land along the Bhavani river is heavily settled, with about to settlements in the Athikadavu valley. "Irulars" are predominant tribal inhabitants. They mainly depend on forests and forest products for their income, though some also practice agriculture.

Eighteen tree species bearing fleshy fruit, preferred by hornbills, were identified in the study area. Ten individuals of each tree species were marked with metal tags (fewer if less were present), for a total of 147 individuals. Seven 
species were figs (Ficus spp.) and 11 non-figs. Phenological observations were made once a fortnight, from December 2000 to December 2001, along a $4 \mathrm{~km}$ transect in the riverine forest. For each census, we visited tagged trees and estimated the percentage of canopy covered in ripe and unripe fruit. Determination of ripe versus unripe fruit was based primarily on colour (Anggraini et al. 2000). We used a scale of $0-4$, where $\mathrm{o}=$ no fruits, $1=1-25 \%, 2=26-50 \%, 3=51-75 \%$ and $4=76-100 \%$ canopy coverage.

The breeding season is defined as the duration between the day of complete nest sealing and the day on which female and fledglings break out of the nest. Non-breeding season is the period intervening between two successive breeding seasons. During the non-breeding season, we observed foraging birds, at peak feeding times (c. o6h30-09h30 and 16hoo-18hoo), during daily walks along observation trails. When hornbills were sighted on fruit-bearing trees, we recorded tree species, flock size and number of feeding individuals. Feeding activity was recorded as 5 -minute bouts.

An intensive search was conducted in the study-site for nesting Hornbills. Nest-sites were located by following pairs prior to the breeding season, in late January. Two active nests were located, one in Terminalia arjuna (Combretaceae), the other in Madhuca longifolia (Sapotaceae). Both females occupied their nests at the end of February and females and chicks left the nest during the first week of May. Hence March and April were considered peak breeding season. Food delivered by the males to nest inmates was recorded between o6hoo and 18 hoo, for total of 150 hours of observation. Observations were made using a spotting scope from a camouflaged hide opposite the nest-trees. Number of visits by each male, duration of visits, and number and types of food items delivered were recorded. Most fruits delivered could be identified by looking at the colour, size and shape, by comparison with the fruits available in the site and by looking at the middens.

Preference index (PI) was calculated using Ivlev's Index of Selectivity (Ivlev 1961) (PI = U - A/U + A, where U denotes percentage utilization of species and A denotes percentage availability of corresponding species). Values of PI range between -1 and +1 , where -1 indicates avoidance while +1 indicates highest preference.

Local names of the tree species, parts used and usages were documented in interviews with tribal inhabitants. To determine abundance and distribution of food and nest-trees, and document disturbance signs, two belt-transects were laid on the riverbanks. Each was divided into $20 \times 10 \mathrm{~m}$ subplots for recording the trees. A total of 100 subplots, 50 from each of the belt-transect were laid. In each $20 \times 10 \mathrm{~m}$ tree plot, $3 \times 3 \mathrm{~m}$ subplots were laid for recording shrubs, and two $1 \times 1 \mathrm{~m}$ plots were laid for recording herbs. Density, abundance and frequency were calculated for each species. The importance value index (IVI) for each species was computed by summing the relative density, relative frequency and relative dominance.

\section{Results}

\section{Fruit availability}

All 18 marked species fruited during the study period. At least some species of figs and non-figs had fruits during each census. The overall number of tree 
species in fruit was lowest $(n=3)$ during August, increased during the following months and attained a peak $(n=9)$ in February, March. Figs showed seasonality, with six species fruiting in February and March, and only one in August. Non-fig species did not show major fluctuation in fruiting over the year. The fruiting peak of all species, in March, was mainly due to the peak in fig fruiting. Number of individual trees in fruits was low $(n=9)$ in July and increased steadily to a peak $(n=43)$ at summer onset in March. Barring Ficus virens, all fig species had fruits throughout the study period, mainly due to asynchrony in fruit production within individuals of the same species. Among the three non-fig species, two, Strychnos nux-vomica (Loganiaceae) and Putranjiva roxburghii (Euphorbiaceae), showed extended fruiting, lasting throughout the study period; one, Beilschmiedia wightii (Lauraceae), had a short fruiting period.

\section{Fruit utilization}

Seven hundred and ninety-one fruits were delivered during 150 hours of observation, including fruits of 13 plant species (Table 1). During the breeding season, six fruit species formed the diet, of which $75.6 \%$ were figs, primarily Ficus benghalensis (56.05\%) and Putranjiva roxburghii (20.47\%). During the non-breeding season, 551 feeding bouts were recorded, of which figs accounted for $60 \%$; $36.30 \%$ of feeding records were noted on F. benghalensis, followed by Strychnos nux-vomica (19.96\%). Ivlev's preference index showed that the Malabar Pied Hornbill preferred figs, namely F. benghalensis (PI 0.98), F. drupacea (PI 0.93) and F. amplissima (PI 0.93) (Table 2). During both breeding and non-breeding season, fig fruits were preferred. Of the 18 fleshy-fruited species marked for phenology study, five were not consumed.

\section{Vegetation features}

A total of 708 individuals of 62 tree species were recorded from two hectares of riverine forest. However, only 56 species of 24 families could be identified.

Table 1. Characteristics of fruit consumed by Malabar Pied Hornbill.

\begin{tabular}{|c|c|c|c|c|c|}
\hline $\begin{array}{l}\text { Species } \\
\text { no. }\end{array}$ & Botanical name & Family & $\begin{array}{l}\text { Fruit } \\
\text { diameter } \\
(\mathrm{cm})\end{array}$ & Fruit colour & Nutrition type \\
\hline 1 & Azadirachta indica Adr. Juss & Meliaceae & 0.90 & Yellow & Non-fig - sugar \\
\hline 2 & Capparis roxburghii DC. & Capparaceae & 5.00 & Red & Non-fig - sugar \\
\hline 3 & Ficus amplissima Sm. & Moraceae & 1.63 & White & Fig \\
\hline 4 & Ficus benghalensis Linn. & Moraceae & 2.70 & Red & Fig \\
\hline 5 & Ficus drupacea Thunb & Moraceae & 2.24 & Purple & Fig \\
\hline 6 & Ficus racemosa Linn. & Moraceae & 3.01 & Purple & Fig \\
\hline 7 & Ficus religiosa Linn. & Moraceae & 0.83 & Purple & Fig \\
\hline 8 & Litsea sp. & Lauraceae & 0.80 & Black & Lipid \\
\hline 9 & $\begin{array}{l}\text { Madhuca longifolia } \\
\text { (Koenig) MacBride }\end{array}$ & Sapotaceae & 2.00 & Green & Lipid \\
\hline 10 & Putranjiva roxburghii Wall. & Euphorbiaceae & 1.67 & White & Non-fig - sugar \\
\hline 11 & Strychnos nux-vomica Linn. & Loganiaceae & 4.53 & Red & Non-fig - sugar \\
\hline 12 & Strychnos potatorum & Loganiaceae & 1.90 & Black & Non-fig - sugar \\
\hline 13 & $\begin{array}{l}\text { Syzygium cumini } \\
\text { (Linn.) Skeels }\end{array}$ & Myrtaceae & 1.87 & Black & Non-fig - sugar \\
\hline
\end{tabular}


Table 2. Preference inde of fruit trees used by Malabar Pied Hornbill.

\begin{tabular}{lcc}
\hline Species & Preference Index & \\
\cline { 2 - 3 } & Non-breeding season & Breeding season \\
\hline Azadirachta indica & 0.58 & -1 \\
Ficus amplissima & 0.93 & 0.96 \\
Ficus benghalensis & 0.98 & 0.99 \\
Ficus drupacea & 0.93 & 0.88 \\
Ficus racemosa & 0.52 & 0.73 \\
Litsea sp. & 0.46 & -1 \\
Madhuca longifolia & -0.17 & -1 \\
Putranjiva roxburghii & -0.86 & 0.79 \\
Strychnos nux-vomica & 0.71 & -0.23 \\
Strychnos potatorum & 0.83 & -1 \\
Syzygium cumini & 0.12 & -1 \\
\hline
\end{tabular}

Shannon and Wiener's (1963) Diversity Index equalled 3.22. This vegetation community is dominated by Pongamia pinnata (IVI 38.43), and Diospyros peregrina (IVI 34.25) and Terminalia arjuna (IVI 26.99). Other principal tree species include Mangifera indica (IVI 18.88), Madhuca longifolia (IVI 17.11) and Memecylon edule (IVI 15.82). At the family level, Moraceae, with seven tree species, was dominant.

\section{Human disturbances}

Major anthropogenic disturbances were trees with cut signs, evidence of largescale collection of plant parts, and spread of exotic weeds. Of the 457 trees encountered in the first transect ( 1 ha), 33 (7.22\%) had cut signs. Thirteen species are affected by cutting, mainly for firewood. From the riverine forest, six species are over-exploited due to their commercial value. These species form the Non-timber Forest Produces (NTFP) and are collected for their fruits. They are Diospyros peregrina (for dyeing), Garcinia cambogia (as a culinary ingredient), Madhuca longifolia (for oil extraction), Mangifera indica (for pickle making), Sapindus emarginatus (as detergent) and Terminalia arjuna (use not recorded). Memecylon edule is good fodder for livestock and most of the individuals have been chopped. Livestock grazing has cleared areas of herbaceous vegetation including regenerating trees, resulting in the creation of small openings where exotic weeds grow luxuriantly. Shrub-layer data indicate that $42.01 \%$ of individuals were exotic weeds, $25.69 \%$ were native shrubs and $32.30 \%$ were saplings of trees (Table 3). Six species of weeds form a major proportion of shrub flora in Athikadavu valley. The two exotic weed species, Lantana camara and Chromolaena

Table 3. Relative abundance of exotic weeds in the riverine forest, Athikadavu valley ( 1 ha).

\begin{tabular}{lllc}
\hline Type of shrub & No. of species & No. of individuals & Percentage \\
\hline Native shrubs & 20 & 148 & 25.69 \\
Exotic shrubs & 6 & 242 & 42.01 \\
Regeneration class & 27 & 186 & 32.30 \\
All species & 53 & 576 & 100 \\
\hline
\end{tabular}


odorata (=Eupatorium odoratum) with the relative density values of 17.53 and 22.22, were prime colonizers.

\section{Discussion}

Food habits

Important food sources for Malabar Pied Hornbill include species that were preferred, species consumed in large quantities and species that fruited during the lean season. Preferred food trees were figs (Ficus benghalensis, F. drupacea and F. amplissima), found in low densities in the study site. Fruit species consumed in large quantities - Strychnos nux-vomica and Putranjiva roxburghii - were abundant. The neem tree, Azadirachta indica, fruited during June and July, when only a few individuals of $F$. benghalensis fruited in the study site. Except for $A$. indica, all the above-mentioned tree species form part of riparian vegetation. $A$. indica is a deciduous forest element mostly seen on the ecotone areas where the dry mixed deciduous forests and semi-evergreen vegetation merge.

Fig diversity was high ( $n=6$ species), though individual fig species were represented in low densities. Overall density of figs was $7 \cdot 5 \mathrm{ha}^{-1}$, while individual densities ranged from $0.5 \mathrm{ha}^{-1}$ (Ficus amplissima and Ficus virens) to $3 \mathrm{ha}^{-1}$ (Ficus racemosa). This is a higher density than at other sites in South-East Asia (Johns 1983, Leighton and Leighton 1983, Lambert 1991, Lambert and Marshall 1991). The year-round presence and breeding of Malabar Pied Hornbill in Athikadavu valley may be attributed to the high diversity and density of figs, as reported by Kinnaird et al. (1996) in North Sulawesi for the Red-knobbed Hornbill.

Throughout the tropics, fig fruiting occurs year-round, making figs an indispensable resource for tropical frugivores (Foster 1982, Milton et al. 1982, Leighton and Leighton 1983, Terborgh 1986, Windsor et al. 1989, Kinnaird et al. 1996). In Thailand, Poonswad et al. $(1983,1987)$ observed that about $57 \%$ of food items delivered by males to the nest inmates were figs. Figs comprised about $70 \%$ of the diet of Red-knobbed Hornbill Aeros cassidix (Kinnaird and O'Brien 1993). Twenty of the 24 fruit species utilized by Red-knobbed Hornbill were figs in the non-breeding season (Suryadi et al. 1994). Kinnaird et al. (1996) demonstrated that the distribution of fig tree influences spatial patterns in hornbill densities, hornbills preferring areas of high Ficus densities. Kannan and James (1997) observed that about $73 \%$ of food items delivered by a parent hornbill to the nest inmates were fig fruits. O'Brien (1998) observed that for the Northern Sulawesi Tarictic Hornbill Penelopides exarhatus, one third of fruits delivered at the nests were figs. About $60 \%$ of feeding during the non-breeding season by the endemic Malabar Grey Hornbill, in a semi-evergreen forest of Western Ghats, was on figs (Balasubramanian and Maheswaran 2002a).

Large-scale consumption of figs by hornbills may be to maintain an adequate balance of calcium. According to O'Brien et al. (1998) figs contain 3.2 times more calcium than other fruits, high enough to promote eggshell deposition and bone growth in birds.

On Barro Colorado Island in the Neotropics, Windsor et al. (1989) found that fig production peaked during a low point in non-fig fruit production and appeared to sustain bird and mammal population during those periods (Foster 
1982). In the Palaeotropics Borges (1993) found that in one of two sites, fig fruit production peaked when other species experienced a trough in fruiting. Figs were therefore considered a candidate "keystone species" (Terborgh 1986). Kannan (1994) considered figs as keystone resources for Great Pied Hornbill Buceros bicornis in Western Ghats. In Athikadavu valley, figs sustained birds during the lean season and hence may be considered "keystone species".

The importance of non-fig fruit species in the diet of hornbills has not received much attention. In Athikadavu valley, the non-fig tree species Strychnos nuxvomica (Loganiaceae) constituted $20 \%$ of food during the non-breeding season and also formed one of the preferred species. Strychnos nux-vomica had extended fruiting, thereby sustaining the hornbill population for a long period in the non-breeding season. Similarly another non-fig species, Putranjiva roxburghii (Euphorbiaceae), formed $20.7 \%$ of the fruits delivered at the nests, thus constituting a major food source during the breeding season. Oriental Pied Hornbills Anthracoceros albirostris in Thailand utilized $45 \%$ of non-fig fruit species during the breeding season (Poonswad et al. 1983). A study on Red-knobbed Hornbill in the Tangkoko Duasudara Reserve showed that about $20 \%$ of the breeding season diet comprised non-fig species (Kinnaird and O'Brien 1993). Kannan and James (1999) highlighted the role of Vitex altissima, a non-fig species, as a pivotal fruit resource for hornbills in an evergreen forest at Western Ghats. The individuals of this species were in fruit during the fruit-scarce north-east monsoon. In the same site, fruits of a toxic plant species, Strychnos nux-vomica, were also delivered to the nestlings during the breeding period (Kannan and James 1997). Malabar Grey Hornbill, in a semi-evergreen forest at Mudumalai Wildlife Sanctuary, utilized lipid-rich fruits and non-fig sugar-rich fruits during the breeding season, where the lipid-rich Actinodaphne malabarica (Lauraceae) and sugar-rich Olea dioica (Oleaceae) were the preferred fruit species (Balasubramanian and Maheswaran 2002a). About $95 \%$ of the diet consisted of non-fig sugar rich and lipid-rich fruits.

Reddy and Basalingappa (1993) observed that Malabar Pied Hornbills preferred Ficus and Strychnos fruits in North Kanara forests. They further stated that most of the fruit species utilized by this bird species contain a high percentage of water; the most favoured fruits, Strychnos and Ficus benghalensis, contain $79.86 \%$ and $72.90 \%$ water respectively. In this site at Athikadavu also, as recorded in North Kanara forests (Reddy and Basalingappa 1993), Ficus spp. and Strychnos fruits formed the favoured fruits. The preference shown by hornbills for Ficus and Strychnos in both these sites may be to meet their water requirements, as well as to supplement their food with calcium or carbohydrate. While both these fruit species contain meagre quantities of lipid and protein, Strychnos has a higher carbohydrate content (Reddy and Basalingappa 1993).

\section{Status and distribution of Malabar Pied Hornbill in Western Ghats}

Most of the Western Ghats is found in three south Indian states: Tamil Nadu, Karnataka and Kerala. Detailed information on the distribution and conservation status of this threatened hornbill species in these areas is unavailable. However, from secondary sources and our field investigations in southern Western Ghats, inferences can be made. 
In Tamil Nadu state, Malabar Pied Hornbill was reported to occur in Athikadavu valley, altitude $550 \mathrm{~m}$. (Balasubramanian and Maheswaran 2002b). Throughout the year, hornbills were seen here. The riverine forest was used by this species for feeding, roosting and nesting. A maximum of 21 hornbills was sighted together. This area forms one of the few breeding sites of this species in Western Ghats. Major threats noticed here are expansion of agricultural activities by tribals, grazing by goats and cattle, firewood and NTFP collections, sand-quarrying, and fishing.

In Karnataka state, Reddy et al. (1990) recorded this species in the riverine forests of Northern Kanara (altitude 500-600 m). A maximum of 74 hornbills was recorded here. The riverine forests are used for roosting and foraging, the adjoining deciduous forests utilized only for foraging. Hornbills of this area predominantly ate figs and Strychnos. Reddy et al. (1990) quoted that habitat destruction poses a major threat to the survival of this species in the site. Poaching of hornbills by tribals for medicinal use was also reported from this area. A declining trend of the population has been observed.

In Kerala, Zacharias and Gaston (1999) recorded this species from one locality (Nilambur, altitude $60-300 \mathrm{~m}$ ) of the 24 forested areas visited during their 20 year avifauna survey. They reported that the present status of Malabar Pied Hornbill in Kerala is much worse than that described by Ali (1969) for the 1930s. In their view, the lowland forests are the most exploited. At the current pace of habitat destruction these birds may be vulnerable to extirpation from local areas.

\section{Conclusions}

Malabar Pied Hornbill is a frugivore depending mainly on figs, preferring lowland riparian vegetation. The species is disjunctly distributed in Western Ghats and the population is declining due to habitat destruction and poaching. The prime habitat of this species in Western Ghats, the lowland forests, is subjected to severe exploitation for the purposes of agriculture, trade-related exploitation of plant parts, livestock grazing and developmental activities such as hydro-electric projects and industries.

\section{Conservation implications}

Major emphasis should be given to conserving the lowland riparian vegetation in Western Ghats. Expansion of agricultural activities alongside the river should be stopped. Efforts must be taken to link the vegetation fragments along the river systems that support hornbill populations. In order to restore contiguity of the vegetation along the riverbanks, degraded sites should be vegetated with suitable indigenous species. Potential candidates for reforestation should be those tree species that provide food and nesting habitat for hornbills and other hole-nesters. Sand-quarrying must be stopped immediately, as the removal of silt leads to the loss biodiversity, particularly soil microbes and seed banks. Grazing by livestock must be controlled as it leads to the destruction of herbaceous vegetation, paving the way for the invasion of exotic plant species. A campaign should be undertaken in hornbill habitat to create awareness among the forest inhabitants as well as the forest protection staff. Declaration of a few 
hornbill habitats as bird sanctuaries will definitely increase the protection status of this threatened species in Western Ghats.

\section{Acknowledgements}

Thanks are due to Dr V.S. Vijayan, Director, Salim Ali Centre for Ornithology and Natural History (SACON) for his support and encouragement. This paper is an offshoot of a small grant research project sponsored to the first author by SACON. We thank the Chief Wildlife Warden of Tamil Nadu Forest Department for granting us fieldwork permission. We are grateful to the officials of the Tamil Nadu Electricity Board at Athikadavu for providing accommodation at their camp. Sincere thanks are also due to Dr Pilai Poonswad, Hornbill Research Foundation, Thailand.

\section{References}

Ali, S. (1969) Birds of Kerala. Bombay: Oxford University Press.

Ali, S. and Ripley, S. D. (1987) Compact hand book of the birds of India and Pakistan. Second edition. New Delhi: Oxford University Press.

Anggraini, K., Kinnaird, M. F. and O'Brien, T. (2000) The effects of fruit availability and habitat disturbances on an assemblage of Sumatran hornbills. Bird Conserv. Intn. 10: 189-202.

Balasubramanian, P. and Maheswaran, B. (2002a) Studies on hornbill-tree interactions with special reference to identification and conservation of "keystone mutualists" in Nilgiri Biosphere Reserve. Final Report. Coimbatore, India: Salim Ali Centre for Ornithology and Natural History.

Balasubramanian, P. and Maheswaran, B. (2002b) Hornbill-tree interactions with special reference to identification and conservation of "keystone mutualists" in Nilgiri Biosphere Reserve. In J. K. Sharma, P. S. Easa, C. Mohanan, N. Sasidharan and R. K. Rai, eds. Biosphere reserves in India and their management, Ministry of Environment and Forests, Government of India, and Kerala Forest Research Institute, Peechi, India.

Balasubramanian, P., Prasad, S. N. and Kandavel, K. (1998) Role of birds in seed dispersal and natural regeneration of forest plants in Tamil Nadu. Technical Report No. 7. Coimbatore, India: Salim Ali Centre for Ornithology and Natural History.

BirdLife International (2001) The BirdLife International Red Data Book. Cambridge, U.K.: BirdLife International.

Borges, R. M. (1993) Figs, Malabar Giant Squirrels and fruit shortages within two tropical Indian forests. Biotropica 25(2): 183-190.

Dev, U. N. (1992) Rearing of Malabar Pied Hornbill (Anthracoceros coronatus) in Bihang Institute for Ornithology and Mass Education. Bihang Newsletter 1: 1-16.

Foster, R. B. (1982) The seasonal rhythm of fruitfall on Barro Colorado Island. Pp. 151-172 in E. G. Leigh, A. S. Rand and D. M. Windsor, eds. The ecology of tropical forest. Washington, DC: Smithsonian Institution Press.

Ivlev, V. S. (1961) Experimental ecology of the feeding fishes. New Haven, CN: Yale University Press.

Johns, A. (1983) Ecological effects of selective logging in a West Malaysian rain forest. Ph.D. dissertation. Cambridge University, Cambridge, U.K.

Kannan, R. (1994) Ecology and conservation of the Great Pied Hornbill (Buceros bicornis) in the Western Ghats of southern India. Ph.D. dissertation. University of Arkansas, USA.

Kannan, R. and James, D. A. (1997) Breeding biology of the Great Pied Hornbill (Buceros bicornis) in the Western Ghats of southern India. J. Bombay Nat. Hist. Soc. 94: 451-465. 
Kannan, R. and James, D. A. (1999) Fruiting phenology and the conservation of the Great Pied Hornbill (Buceros bicornis) in the Western Ghats of Southern India. Biotropica 31(2): 167-177.

Kemp, A. C. (1995) The hornbills. Oxford: Oxford University Press.

Kinnaird, M. F. and O’Brien, T. G. (1993) Preliminary observations on the breeding biology of the endemic Sulawesi Red-knobbed Hornbill (Rhyticeros cassidix). Trop. Biodiv. 1: 107-112.

Kinnaird, M. F., O’Brien, T. G. and Suryadi, S. (1996) Population fluctuation in Sulawesi Red-knobbed Hornbills: tracking figs in space and time. Auk 113(2): 431-440.

Lambert, F. (1991) The conservation of fig-eating birds in Malaysia. Biol. Conserv. 58: 31-40.

Lambert, F. R. and Marshall, A. G. (1991) Keystone characteristics of bird-dispersed Ficus in a Malaysian lowland rain forest. J. Ecol. 99: 793-809.

Leighton, M. and Leighton, D. R. (1983) Vertebrate responses to fruiting seasonality within a Bornean rainforest. Pp. 181-209 in S. L. Sutton, T. C. Whitmore and A. C. Chadwick, eds. Tropical rainforests: ecology and management. Oxford: Blackwell Scientific.

Milton, K., Windsor, D. M., Morrison, D. W. and Estribi, M. (1982) Fruiting phenologies of two Neotropical Ficus species. Ecology 63: 752-762.

O'Brien, T. G. (1997). Behavioural ecology of the North Sulawesi Tarictic Hornbill Penelopides exarhatus during the breeding season. Ibis 139: 97-101.

O’Brien, T. G., Kinnaird, M. F., Dierenfled, E. S., Conklin-Brittain, N. L., Wrangham, R. W. and Silver, S. C. (1998) What's so special about figs? Nature 392: 668.

Patel, A. (1997) Phenological patterns of Ficus in relation to other forest trees in southern India. J. Trop. Ecol. 13: 681-695.

Poonswad, P., Tsuji, A. and Ngarmporgsai, C. (1983) A study of the breeding biology of hornbills (Bucerotidae) in Thailand. Pp. 239-265 in Proceedings of the Jean Delacour/IFCB symposium on breeding birds in captivity. North Hollywood, CA: International Foundation for the Conservation of Birds.

Poonswad, P, Tsuji, A. and Ngampongsai, C. (1987) A comparative study on breeding biology of sympatric hornbill species (Bucerotidae) in Thailand with implications for breeding in captivity. Pp. 250-315 in Proceedings of the Jean Delacour/IFCB symposium on breeding birds in captivity. North Hollywood, CA: International Foundation for the Conservation of Birds.

Reddy, M. S. and Basalingappa, S. (1993) The food of the Malabar Pied Hornbill. J. Ecol. Soc. 8: 23-28.

Reddy, M. S., Muralidhar, K. S., Gandhi, M. R. and Basalingappa, S. (1990) Distribution and variation in number of Malabar pied hornbills (Anthracoceros coronatus Boddaert) in selected areas of North Kanara forests of Western Ghats in Karanataka, India. Indian Zool. 14(1/2): 63-73.

Ripley, S. D. (1982) Synopsis of the birds of India and Pakistan. Second edition. Bombay: Bombay Natural History Society.

Robbins, C. T. (1993) Wildlife feeding and nutrition. New York: Academic Press.

Shannon, C. I. and Wiener, W. (1963) The mathematical theory of communication. Urbana, IL: University of Illinois Press.

Suryadi, S., Kinnaird, M. F., O’Brien, T. G., Suprianta, J. and Somadikarta, S. (1994) Food preferences of Sulawesi Red-knobbed Hornbill during the non-breeding season. Trop. Biodiv. 2: $377-384$.

Terborgh, J. (1986) Keystone plant resources in the tropical forest. Pp. 330-344 in M. Soule, ed. Conservation biology. Sunderland, MA: Sinauer Associates.

Tikadar, B. K. (1983) Threatened animals of India. Calcutta: Zoological Survey of India.

Windsor, D. M., Morrison, D. W., Estribi, M. A. and Leon, B. (1989) Phenology of fruit and leaf production by "strangler" figs on Barro Colorado Island, Panama. Experientia 45: 647-653. 
Zacharias, V. J. and Gaston, A. J. (1999) The recent distribution of endemic, disjunct and globally uncommon birds in the forests of Kerala State, south-west India. Bird Conserv. Intn. 9: 191-225.

P. BALASUBRAMANIAN*, R. SARAVANAN and B. MAHESWARAN

Salim Ali Centre for Ornithology and Natural History, Coimbatore 641 108, Tamil Nadu, India (e-mail:balusacon@yahoo.com)

*Corresponding author. 